\title{
JAUNŲ KREPŠININKŲ ŠIRDIES KAIRIOJO SKILVELIO STRUKTÜRA IR FUNKCIJA
}

\author{
Tomas Venckūnas ${ }^{1}$, Donatas Vasiliauskas², Jolanta Marcinkevičiené², Rasa Raugaliene் $\dot{e}^{2}$ \\ Lietuvos kūno kultūros akademija ${ }^{1}$, Kauno medicinos universiteto Kardiologijos institutas ${ }^{2}$, Kaunas, \\ Lietuva
}

Tomas Venckūnas. Biomedicinos mokslų daktaras. Lietuvos kūno kultūros akademijos Taikomosios fiziologijos ir sveikatos ugdymo katedros asistentas. Mokslinių tyrimų kryptis — ištvermès treniruotès poveikis širdies struktūrai ir funkcijai.

\begin{abstract}
SANTRAUKA
Krepšininkušsirdies struktūra ir funkcija yra labai mažai tirta, todè šio tyrimo tikslas —ivertinti jaunu populiariausios Lietuvoje sporto šakos atstovu širdies struktūrinès adaptacijos pobūdị ir masta.

29 krepšininkams, kuriu amžius nuo 9 iki 28 metu, ir 7 sveikiems 18-25 metu nesportuojantiems vyrams buvo atlikta standartine dvimate M-režimo ir Doplerio echokardiografija. Diastolés pabaigoje buvo matuojamas tarpskilvelinès pertvaros storis, kairiojo skilvelio (KS) vidinis skersmuo ir KS užpakalinès sienelès storis. Santykinis KS sienelès storis apskaičiuotas tarpskilvelinès pertvaros ir užpakalinès KS sienelès storiu sumq dalijant iš vidinio KS skersmens. KS masè buvo apskaičiuojama pagal standartine formulę. KS diastolinè funkcija buvo èvertinta pulsiniu Dopleriu išmatavus maksimaliuosius (ankstyva (E) ir dèl prieširdžiu susitraukimo (A) pro mitralinì vožtuva tekančio kraujo) greičius bei apskaičiavus ju santyki ( $E$ / A).

Krepšininku širdies dydis dangiausia priklausè nuo ju kūno dydžio. Lvairaus amžiaus ir treniruotumo sportininku absoliutus KS vidinis skersmuo skyrėsi reikšmingai, santykinis nesiskyré ( $p>0$,05). Santykinis suaugusiu krepšininku KS skersmuo nesiskyrè $(p>0,05)$, tačiau tiek absoliuti, tiek santykinè KS mase buvo didesnè $(p<0,05)$ nei sveiku nesportuojančiu bendraamžiu. Be to, skirtingu amžiaus grupiu krepšininku santykinis KS sienelès storis (miokardo koncentriškumo rodiklis) buvo didesnis už nesportuojančiuju. Krepšininku diastolinès KS funkcijos sutrikimo požymiu nenustatyta, o atletu indeksas E / A, nors nereikšmingai, tačiau buvo didesnis už sveiku nesportuojančiu asmenu $(p>0,05)$.

Jei krepšinio treniruote ir sukelia jaunu vyru širdies KS hipertrofija, miokardo persimodeliavimas (visu pirma dèl fiziologiškai sustorèjusiu sieneliu) būna tik saikus ir priklauso nuo sportininko amžiaus bei treniravimosi stažo.
\end{abstract}

Raktažodžiai: antropometriniai rodikliai, echokardiografija, kairiojo širdies skilvelio hipertrofija, krepšinis.

\section{IVADAS}

$\mathrm{R}$ eguliari didelès apimties fizinè veikla gali sukelti širdies raumens hipertrofiją. Nors intensyviai besitreniruojančių vaiku ir paauglių yra daug, apie tokios veiklos ittaką jų širdies struktūrai ir funkcijai žinoma gerokai mažiau nei apie suaugusiuju (Pavlik et al., 2001; Triposkiadis et al., 2001; Sharma, 2003). Jaunų (maždaug iki 17 metų amžiaus) krepšininkų miokardo hipertrofija natūraliai vystosi dèl intensyvaus organizmo augimo ir galbūt dèl reguliarios hemodinaminès miokardo apkrovos krepšinio treniruotès metu. Pe- diatrams būtina žinoti ne tik apie bendrosios populiacijos širdies hipertrofija, bet ir apie galima jaunu sportininkų miokardo persimodeliavimo dydi dèl reguliarios fizinès veiklos (pvz., krepšinio treniruotès), nes tai leidžia atskirti fiziologinę adaptaciją nuo širdies ir kraujagysliu sistemos ligu ar ju pasekmiu (Rowland et al., 1987; Triposkiadis et al., 2001). Suaugusių krepšininkų širdies struktūra ir funkcija iki šiol taip pat labai mažai tirta. Šiuo tyrimu norejome ịvertinti jaunų krepšininkų širdies struktūrinę adaptaciją. 


\section{TYRIMO METODAI}

Tiriamieji. Tirti 29 bent trejus metus reguliariai sportuojantys 9-28 metu krepšininkai (dešimt 9-12 metų, vienuolika 13-16 metų, aštuoni 17-28 metų amžiaus) ir 7 sveiki nesportuojantys $18-25$ metú amžiaus vyrai. Sportininkai tyrimo laikotarpiu treniravosi mažiausiai 5 kartus per savaitę, dalyvavo varžybose.

Visų grupių tiriamujų amžiaus, antropometrinių rodikliu vidurkiai ir standartiniai nuokrypiai pateikti 1 lenteleje.

Echokardiografija. Tiriamieji prieš echokardiografini tyrimą bent $12 \mathrm{~h}$ nesportavo ir $2 \mathrm{~h}$ nevalgè. Tiriamiesiems gulint ant kairio šono, ultragarsiniu aparatu AU3 Partner (Esaote Biomedica, Genuja, Italija) su 2,5 MHz davikliu buvo atliekama standartine transtorakaline $\mathrm{M}$ ir $2 \mathrm{D}$ režimu echokardiografija. Buvo atliekami parasternalinès ilgosios ašies matavimai: pagal Amerikos echokardiografijos asociacijos rekomendacijas (Sahn et al., 1978) diastolès pabaigoje išmatuotas tarpskilvelines pertvaros storis, KS vidinis skersmuo ir užpakalinès sienelès storis. Kraujo tekejjimo pro mitralini vožtuvą greitis buvo matuotas Doplerio efektu. Licenciją turintis kardiologas atliko tris kiekvieno rodiklio matavimus, paskui buvo apskaičiuojamas vidurkis.

KS masę apskaičiavome taikydami Penn konvencijoje priimtą R. B. Devereux (Devereux et al., 1986) formulès korekciją:

$\mathrm{KS}$ mase $(\mathrm{g})=1,04 \times[(\mathrm{TPd}+\mathrm{KSSd}+$ $\left.\left.\mathrm{KSUSd})^{3}-\mathrm{KSSd}^{3}\right]\right\}-13,6$,

čia TPd - tarpskilvelinès pertvaros storis diastolès pabaigoje, KSSd - KS vidinis skersmuo diastolès pabaigoje, KSUSd - KS užpakalinès sienelès storis diastolès pabaigoje $(\mathrm{cm})$.

KS masès indeksą apskaičiavome KS masę dalydami iš kūno paviršiaus ploto. Pagal Europos kardiologų ir Hipertenzijos draugijų rekomendaciją KS laikėme hipertrofuotu tada, kai jo masès indeksas didesnis nei $125 \mathrm{~g} / \mathrm{m}^{2}$. Be to, G. de Simone ir bendraautoriu siūlymu, lygindami skirtingų antropometrinių duomenų asmenų KS masę, ją dalijome iš ūgio (m), pakelto 2,71828 (e) laipsniu (de Simone et al., 1992). Santykini KS sienelès stori apskaičiavome KS užpakalinès sienelès ir tarpskilvelinès pertvaros storių sumą dalydami iš KS skersmens.

Kadangi tyrème ne tik skirtingo amžiaus krepšininkus, bet ir lyginome jų duomenis su nesportuojančiujų (mažesnio ūgio asmenu) (1 lent.) duomenimis, taikème vengrų kardiologų pasiūlytą modelį ir, skaičiuodami santykinius širdies struktūros rodiklius, tarpskilvelinès pertvaros, KS užpakalinès sienelès storị ir ertmès skersmeni dalijome iš kūno paviršiaus ploto (KPP), pakelto $1 / 2$ laipsnio (KPP, $\left.\mathrm{m}^{2}\right)^{1 / 2}$ (Gutgesell, Rembold, 1990; George et al., 1999; Pavlik et al., 2001).

Pulsiniu Dopleriu diastolès metu išmatavome maksimaliuosius (ankstyvą (E) ir dèl prieširdžiu (A) susitraukimo mitralini vožtuvą tekančio kraujo) greičius ( $\mathrm{m} / \mathrm{s})$. Vertindami diastolinę funkciją, apskaičiavome jų santyki (E / A).

Anketavimas ir antropometriniai matavimai. Visi tiriamieji gavo anketą, kurioje turejo nurodyti savo amžių, o krepšininkai - ir treniravimosi stažą. Prieš echokardiografiją tiriamieji pasverti, pamatuotas jų ūgis. Kūno paviršiaus plotas (KPP) buvo apskaičiuojamas naudojant tokią formulę (Du Bois, D., Du Bois, E. F., 1916): $\operatorname{KPP}\left(\mathrm{m}^{2}\right)=\bar{u}$ gis $(\mathrm{cm})^{0,725} \times$ kūno masè $(\mathrm{kg})$ $0,425 \times 0,007184$

Matematinė statistika. Naudodami kompiuterinę programą Microsoft Excel, apskaičiavome aritmetinius rodikliu vidurkius ir standartinius nuokrypius. Tikimybiniam ryšiui tarp dviejų rodiklių ivvertinti apskaičiavome koreliacijos koefi-

\begin{tabular}{|c|c|c|c|c|c|c|}
\hline \multirow[t]{7}{*}{1 lentelè. Tiriamųjų charakteristika } & & \multicolumn{3}{|c|}{ Sportininkų grupès } & \multirow[b]{2}{*}{$\begin{array}{l}\text { Sveikų } \\
\text { nesportuojančiujų } \\
(\mathrm{n}=7)\end{array}$} & \multirow{2}{*}{$\begin{array}{l}\text { Skirtumo tarp 17- } \\
28 \text { metú amžiaus } \\
\text { sportininkų ir } \\
\text { nesportuojančiujų } \\
\text { reikšmingumas }\end{array}$} \\
\hline & Rodiklis & $\begin{array}{c}9-12 \\
\text { metų } \\
\text { amžiaus } \\
(n=10)\end{array}$ & $\begin{array}{l}13-16 \\
\text { metų } \\
\text { amžiaus } \\
(\mathrm{n}=11)\end{array}$ & $\begin{array}{l}17-28 \\
\text { metų } \\
\text { amžiaus } \\
(\mathrm{n}=8)\end{array}$ & & \\
\hline & Amžius, metai & $10,9(1,1)$ & $14,2(1,2)$ & $20,4(4,7)$ & $22,0(2,4)$ & $\mathrm{p}>0,05$ \\
\hline & Ūgis, $m$ & $1,50(0,10)$ & $1,75(0,13)$ & $1,93(0,06)$ & $1,84(0,05)$ & $\mathrm{p}<0,01$ \\
\hline & Kūno masè, $\mathrm{kg}$ & $38,2(7,2)$ & $59,4(15,3)$ & $84,1(11,5)$ & $75,3(5,8)$ & $\mathrm{p}>0,05$ \\
\hline & $\begin{array}{l}\text { Kūno masès } \\
\text { indeksas, } \mathrm{kg} / \mathrm{m}^{2}\end{array}$ & $16,9(2,2)$ & $19,1(2,4)$ & $22,6(2,3)$ & $22,3(1,6)$ & $p>0,05$ \\
\hline & $\begin{array}{l}\text { Kūno paviršiaus } \\
\text { plotas, } \mathrm{m}^{2}\end{array}$ & $1,28(0,16)$ & $1,72(0,28)$ & $2,14(0,16)$ & $1,97(0,09)$ & $\mathrm{p}<0,05$ \\
\hline $\begin{array}{l}\text { Pastaba. Pateikti rodiklių vidurkiai, } \\
\text { skliaustuose - standartiniai nuokry- } \\
\text { piai. }\end{array}$ & $\begin{array}{l}\text { Treniravimosi } \\
\text { stažas, metai }\end{array}$ & $4,1(1,0)$ & $6,3(1,2)$ & $11,1(4,8)$ & & \\
\hline
\end{tabular}


cientus. Tikrindami hipotezę apie populiaciju vidurkiu lygybę, taikème nepriklausomų imčiu Stjudento kriteriju (t). Reikšmingumo lygmeni pasirinkome 0,05 .

\section{REZULTATAI}

Visų pagrindinių echokardiografinių parametrų tiriamų grupių vidurkiai ir standartiniai nuokrypiai pateikti 2 lentelèje.

Pagal standartini skaičiavimą (KS masę dalijant iš kūno paviršiaus ploto) nè vienam iš tirtų vaikų (9-12 metu) amžiaus krepšininkų nenustatyta KS hipertrofija, tik trijų iš 11 paauglių (1316 metu) amžiaus $(27,3 \%)$ ir 6 iš $817-28$ metu amžiaus (75\%) žaidèju KS masès indeksas buvo didesnis nei $125 \mathrm{~g} / \mathrm{m}^{2}$. Vieno kontrolinès grupès tiriamojo KS taip pat buvo padidèjęs.

Didesni nei 0,45 santykini KS sienelès stori (koncentrinę hipertrofiją) nustateme tik vienam krepšininkui. Jis buvo 15 metų amžiaus, treniravimosi stažas - šešeri metai. Patologiją atmetème, nes E / A buvo apie 2, santykis tarpskilvelinès pertvaros ir užpakalinès KS sienelès storių santykis diastolès pabaigoje - apie 1 (t. y. normalūs, beje, kaip ir visu tirtujų); be to, sportininkas savijauta nesiskundè. Mažesnis nei 0,30 santykinis KS sienelès storis (ekscentrinis persimode- liavimas) neaptiktas nè pas vieną iš tirtų asmenų.

Nẻ vieno iš tirtų krepšininkų ar kontrolinès grupès asmenų diastolinis tarpskilvelinès pertvaros ar KS užpakalinès sienelès storis nebuvo didesnis kaip $12 \mathrm{~mm}$, tačiau vieno 16 metų amžiaus krepšininko vidinis KS skersmuo diastolès pabaigoje buvo net $62 \mathrm{~mm}$.

Koreliacinè analizè, atlikta sujungus visas tris krepšininkų grupes ị vieną $(\mathrm{n}=29)$, parodè, kad ju amžius turèjo ryši su absoliučiais KS dydžio rodikliais $(\mathrm{r}=0,60-0,82, \mathrm{p}<0,05)$. Be to, sportininkų amžius reikšmingai $(\mathrm{p}<0,05)$ koreliavo ir su KS masès indeksu, išreikštu $\mathrm{g} / \mathrm{m}^{2}(\mathrm{r}=0,76)$ ar $\mathrm{g} / \mathrm{m}^{\mathrm{e}}(\mathrm{r}=0,67)$. Su kitais santykiniais KS dydžio (ir diastolinès funkcijos) parametrais nustatyta atvirkštinè krepšininku amžiaus koreliacija $(\mathrm{r} \approx-0,60, \mathrm{p}<0,05)$. Tai lèmé didesni vyresniu sportininku antropometriniai rodikliai, nes jie šiek tiek stipriau nei treniravimosi stažas koreliavo su morfologiniais miokardo parametrais. Santykinis KS sienelès storis, nors vaikų ir paauglių reikšmingai skyrèsi $(p<0,01)$, nebuvo susijęs su sportininkų amžiumi $(p>0,05)$. Nei krepšininkų treniravimosi stažas, nei antropometriniai rodikliai reikšmingai nekoreliavo su KS diastolinès funkcijos parametrais $(\mathrm{p}>0,05)$.

2 lentelè. Tiriamųjų echokardiografiniai rodikliai

\begin{tabular}{|c|c|c|c|c|c|c|c|c|}
\hline \multirow[b]{2}{*}{ Rodiklis } & \multicolumn{3}{|c|}{ Krepšininkų } & \multirow{2}{*}{$\begin{array}{c}\text { Sveikų } \\
\text { nesportuojančiu } \\
\text { suaugusiujuc } \\
(\mathrm{n}=7)\end{array}$} & \multicolumn{4}{|c|}{ Skirtumo reikšmingumas } \\
\hline & $\begin{array}{c}9-12 \text { metų } \\
\text { vaikų } \\
(\mathrm{n}=10)\end{array}$ & $\begin{array}{c}13-16 \\
\text { metų } \\
\text { paauglių } \\
(\mathrm{n}=11)\end{array}$ & $\begin{array}{c}17-28 \text { metų } \\
\text { amžiaus } \\
(\mathrm{n}=8)\end{array}$ & & $\begin{array}{l}\text { Vaiku, } \\
\text { palyginti su } \\
\text { paauglių }\end{array}$ & $\begin{array}{l}\text { Paaugliu, } \\
\text { palyginti su } \\
\text { suaugusių } \\
\text { sportininkų } \\
\end{array}$ & $\begin{array}{c}\text { Paaugliu, } \\
\text { palyginti su } \\
\text { sveiku } \\
\text { nesportuojančiuju } \\
\end{array}$ & $\begin{array}{c}17-28 \text { metų } \\
\text { sportininkų, } \\
\text { palyginti su sveikų } \\
\text { nesportuojančiujuc }\end{array}$ \\
\hline TP storis, mm & $8,13(0,68)$ & $10,15(0,75)$ & $11,10(0,66)$ & $9,01(0,62)$ & $\mathrm{p}<0,001$ & $\mathrm{p}<0,05$ & $\mathrm{p}<0,01$ & $\mathrm{p}<0,001$ \\
\hline $\begin{array}{l}\text { TP storis, } \mathrm{mm} /(\mathrm{KPP}, \\
\left.\mathrm{m}^{2}\right)^{1 / 2}\end{array}$ & $7,21(0,43)$ & $7,79(0,53)$ & $7,60(0,46)$ & $6,41(0,40)$ & $\mathrm{p}<0,05$ & $\mathrm{p}>0,05$ & $\mathrm{p}<0,001$ & $\mathrm{p}<0,001$ \\
\hline $\begin{array}{l}\text { KS užpakalinès sienelès } \\
\text { storis, } \mathrm{mm}\end{array}$ & $7,92(0,67)$ & $9,98(0,83)$ & $11,10(0,76)$ & $9,97(0,89)$ & $\mathrm{p}<0,001$ & $p<0,01$ & $\mathrm{p}>0,05$ & $\mathrm{p}<0,05$ \\
\hline $\begin{array}{l}\text { KS užpakalinės sienelès } \\
\text { storis, } \mathrm{mm} /\left(\mathrm{KPP}, \mathrm{m}^{2}\right)^{1 / 2}\end{array}$ & $7,03(0,46)$ & $7,65(0,32)$ & $7,59(0,41)$ & $7,10(0,65)$ & $\mathrm{p}<0,01$ & $\mathrm{p}>0,05$ & $\mathrm{p}<0,05$ & $\mathrm{p}>0,05$ \\
\hline $\mathrm{KS}$ vidinis skersmuo, $\mathrm{mm}$ & $41,86(2,65)$ & $48,19(5,09)$ & $55,50(3,59)$ & $52,77(2,15)$ & $\mathrm{p}<0,01$ & $\mathrm{p}<0,01$ & $\mathrm{p}<0,05$ & $\mathrm{p}>0,05$ \\
\hline $\begin{array}{l}\mathrm{KS} \text { vidinis skersmuo, } \\
\mathrm{mm} /\left(\mathrm{KPP}, \mathrm{m}^{2}\right)^{1 / 2}\end{array}$ & $37,15(1,45)$ & $36,93(2,43)$ & $37,97(1,84)$ & $37,58(1,65)$ & $\mathrm{p}>0,05$ & $\mathrm{p}>0,05$ & $\mathrm{p}>0,05$ & $\mathrm{p}>0,05$ \\
\hline $\begin{array}{l}\text { Santykinis KS sienelès } \\
\text { storis }\end{array}$ & $0,383(0,018)$ & $\begin{array}{c}0,420 \\
(0,032)\end{array}$ & $\begin{array}{c}0,401 \\
(0,028)\end{array}$ & $0,360(0,023)$ & $\mathrm{p}<\mathbf{0 , 0 1}$ & $\mathrm{p}>0,05$ & $\mathrm{p}<0,001$ & $\mathrm{p}<0,01$ \\
\hline KS masė, $g$ & $\begin{array}{l}113,50 \\
(22,78) \\
\end{array}$ & $\begin{array}{l}205,18 \\
(55,68) \\
\end{array}$ & $\begin{array}{l}298,32 \\
(48,46) \\
\end{array}$ & $218,76(32,19)$ & $\mathrm{p}<0,001$ & $\mathrm{p}<0,01$ & $\mathrm{p}>0,05$ & $\mathrm{p}<0,01$ \\
\hline $\begin{array}{l}\mathrm{KS} \text { masès indeksas, } \\
\mathrm{g} / \mathrm{m}^{2}\end{array}$ & $88,45(12,77)$ & $\begin{array}{r}118,54 \\
(16,54) \\
\end{array}$ & $\begin{array}{l}139,11 \\
(16,34) \\
\end{array}$ & $110,90(16,00)$ & $\mathrm{p}<0,001$ & $\mathrm{p}<0,05$ & $\mathrm{p}>0,05$ & $\mathrm{p}<0,01$ \\
\hline $\begin{array}{l}\text { KS masès indeksas, } \\
\mathrm{g} / \mathrm{m}^{\mathrm{e}}\end{array}$ & $37,53(6,30)$ & $44,38(5,68)$ & $50,18(6,72)$ & $42,08(7,62)$ & $\mathrm{p}<\mathbf{0 , 0 5}$ & $\mathrm{p}>0,05$ & $\mathrm{p}=0,05$ & $\mathrm{p}<0,05$ \\
\hline $\mathrm{E}, \mathrm{m} / \mathrm{s}$ & $0,91(0,14)$ & $1,00(0,13)$ & $0,88(0,12)$ & $0,75(0,06)$ & $\mathrm{p}>0,05$ & $p>0,05$ & $\mathrm{p}<0,001$ & $\mathrm{p}<0,05$ \\
\hline $\mathrm{A}, \mathrm{m} / \mathrm{s}$ & $0,55(0,05)$ & $0,54(0,07)$ & $0,46(0,060)$ & $0,43(0,07)$ & $\mathrm{p}>0,05$ & $\mathrm{p}<\mathbf{0 , 0 1}$ & $\mathrm{p}<\mathbf{0 , 0 1}$ & $p>0,05$ \\
\hline $\mathrm{E} / \mathrm{A}$ & $1,66(0,361)$ & $1,85(0,19)$ & $1,91(0,45)$ & $1,75(0,26)$ & $\mathrm{p}>0,05$ & $p>0,05$ & $\mathrm{p}>0,05$ & $\mathrm{p}>0,05$ \\
\hline
\end{tabular}

Pastaba. A — didžiausias kraujotakos pro mitralinį vožtuvą greitis dėl prieširdžio susitraukimo (diastolès pabaigoje); E — didžiausias kraujotakos pro mitralini vožtuvą greitis diastolès pradžioje; KPP — kūno paviršiaus plotas; KS — kairysis širdies skilvelis; TP — tarpskilvelinė pertvara. Pateikti rodiklių vidurkiai, skliaustuose — standartiniai nuokrypiai. 


\section{REZULTATŲ APTARIMAS}

Reikia paminèti, kad daugelis, ypač didelès apimties, atletų echokardiografinių tyrimu yra atlikta tose šalyse, kuriose krepšinis nèra populiarus. Šalyse, kuriose krepšinis — populiari sporto šaka, atletų širdies tyrimas ultragarsu nėra privalomas.

Miokardo adaptacija prie nuolatinio ištvermès fizinio krūvio dažnai pasireiškia jau profesionalios sportinès karjeros pradžioje: širdies kameru persimodeliavimas (reikšmingai padidejusios ertmès ir sustorèjusios sienelès) nustatytas 17-mečiams plento dviratininkams (Hoogsteen et al., 2003), futbolininkams (Somauroo et al., 2001) ir ivvairių kitų ištvermès šakų 14-18 metų amžiaus sportininkams (Sharma et al., 2002). Ištyrę daugiau kaip 700 ìvairių ištvermès šakų 14-18 metų amžiaus sportininku, Didžiosios Britanijos mokslininkai nustatè, kad jų KS užpakalinès sienelès storis diastolès pabaigoje siekia 9,5 $\pm 1,7 \mathrm{~mm}$ (Sharma et al., 2002). Tai daugmaž atitinka mūsų gautus 1316 metų amžiaus krepšininkų šio KS hipertrofijos rodiklio duomenis $(9,98 \pm 0,83 \mathrm{~mm})$. Minèti mokslininkai rekomenduoja jaunesniems nei 18 metu ištvermès šakų sportininkams įtarus hipertrofinę kardiomiopatiją tirti nuodugniau tik tuomet, kai ju KS užpakalinès sienelès storis diastolès pabaigoje (ypač jei nèra ertmès dilatacijos) yra didesnis nei $12 \mathrm{~mm}$ (vaikinu) arba $11 \mathrm{~mm}$ (merginu).

Duomenys apie širdies ertmių dilataciją sportininko karjeros metu yra prieštaringi: vieni tyrejjai teigia, kad tai vyksta (Hoogsteen et al., 2003), o kiti - ne: buvo nustatyta, kad jaunu suaugusių ilgiausiujų nuotolių triatlonininkų (labai daug besitreniruojančiu) KS diastolinis skersmuo nesiskyrè nuo vyresnių kolegu (Douglas et al., 1992).

Ištyrę beveik 400 ivvairių šakų 9-20 metu amžiaus sportininkų (vyru), vengrų mokslininkai nustatè, kad 11-12 metų amžiaus sportininkų KS masès indeksas yra didesnis už sveikų nesportuojančių bendraamžių. Tai lemia storesnès miokardo sienelès, o sportininkų KS ertmè nuo nesportuojančių bendraamžių pradeda skirtis tik nuo 15-16 metu amžiaus (Manolas et al., 2001). Idomu tai, kad tyrëjai neaptiko reikšmingos reguliariai sportuojančių jaunesnių nei 11 metų vaikų struktūrinès miokardo adaptacijos (Manolas et al., 2001). Nuo šių autorių pateikiamų rezultatų mūsiškiai šiek tiek skiriasi - matyt, dèl sporto pratybų metu atsirandančios hemodinaminès miokardo perkrovos skirtumų.
Dvylikamečių graikų plaukikų, besitreniruojančių kasdien po 2 valandas, santykinis KS skersmuo diastolès pabaigoje buvo reikšmingai $(\mathrm{p}<0,02)$ didesnis už sveikų nesportuojančių bendraamžiu (atitinkamai 32,3 $\pm 3,3$ ir $\left.29,5 \pm 3,3 \mathrm{~mm} / \mathrm{m}^{2}\right)$, o tarpskilvelinès pertvaros (atitinkamai 5,9 $\pm 1,0$ ir $5,6 \pm 0,8 \mathrm{~mm} / \mathrm{m}^{2}$ ) ir užpakalinès sienelès (atitinkamai $5,7 \pm 0,9$ ir $5,4 \pm 0,8 \mathrm{~mm} / \mathrm{m}^{2}$ ) storis reikšmingai nesiskyrè $(\mathrm{p}>0,05)$ (Triposkiadis et al., 2001). Reguliariai ir daug besitreniruojančiuc vaikų amžiaus plaukikų ekscentrinè miokardo hipertrofija echokardiografiškai buvo nustatyta ir kitų mokslininkų (Rowland et al., 1987). Ankstesni echokardiografiniai tyrimai rodo, kad net geriausiuju vaiku amžiaus plaukikų širdies KS ertmès dydis nesiskyrè nuo nesportuojančių bendraamžių (Allen et al., 1977). Rezultatų neatitikimą galejjo lemti padidintas jaunų plaukikų treniruotès krūvis, ankstesnè reguliaraus treniravimosi pradžia bei atrankos ypatumai. Ir pastaruoju metu nustatoma, kad kai kurių šakų sportininkų vidutinis KS skersmuo nesiskiria nuo sveiku nesportuojančiu bendraamžių (George et al., 1999).

J. Makan su bendraautoriais (2005), ištyrę 900 14-18 metų ištvermès šakų sportininkų ir žaidejjų (ne krepšininku), 250 sveikų nesportuojančių tokiu pat antropometriniu duomenu ju bendraamžių, nustatė reikšmingą $(\mathrm{p}<0,05)$ skirtumą tarp atletų ir nesportuojančiujų echokardiografinių rodiklių, tarp jų ir vidinio KS skersmens. Nè vienam iš savo tirtų sportininkų nenustatę didesnio kaip $60 \mathrm{~mm}$ KS vidinio skersmens, Didžiosios Britanijos mokslininkai nurodo, kad tokiu tarp jaunesnių nei 18 metų sportininkų gali pasitaikyti labai retai, ir tada reikètų ištirti, ar nèra dilatacinès kardiomiopatijos (Makan et al., 2005).

Atlikto tyrimo duomenys leidžia manyti, kad krepšinio treniruote kitaip veikia jaunesnių kaip 12 metų vaikų širdies struktūrą nei plaukimo treniruote. Vis tik norint patvirtinti, kad taip yra iš tiesų, reikia išsamesnių ir didesnès apimties Łvairių sporto šakų vaikų amžiaus atletų tyrimų.

Gautų duomenų lyginimas su kitų autorių pateikiamais leidžia manyti, kad 13-16 metu krepšininkų širdies struktūros tipas skiriasi nuo kitų sportinių žaidimų atstovų, taip pat ir nuo ištvermès šakų sportininkų. Panašaus kūno paviršiaus ploto ir fizinio aktyvumo tos pačios amžiaus grupès kitų sportinių žaidimų atstovų ir ištvermę lavinančiu atletų vidutinis diastolinis KS skersmuo nustatytas didesnis, o sienelès storis - 
mažesnis už mūsų tirtų krepšininkų. Tyrimo metu išmatuotas vidutinis 13-16 metų amžiaus krepšininkų KS vidinis skersmuo diastolès pabaigoje yra toks pat, kaip to paties kūno paviršiaus ploto ir amžiaus nesportuojančiujų (Makan et al., 2005) ar jaunų suaugusių nesportuojančiujų (George et al., 1999). Taigi intensyvi krepšinio treniruote, remiantis atlikto tyrimo rezultatais, reikšmingai nepaveikia paauglių KS talpos, esant ramybès būsenai. Panašius rezultatus yra gavę ir kiti autoriai, nustatę, kad po KS ertmès skersmens korekcijos pagal kūno raumenų masę jaunų kalnų dvikovininkų KS ertmė nesiskyrè nuo nesportuojančiuju (George et al., 1999). Vis tik krepšininkų, kurie dažnai yra gerokai didesni už kitus sportininkus, morfologiniai KS hipertrofijos ir dilatacijos rodikliai gali būti natūraliai didesni. Vieno 16 metų vidurio puolejo, turejusio didžiausią iš mūsu tirtu paaugliško amžiaus krepšininku kūno paviršiaus plotą $\left(2,12 \mathrm{~m}^{2}\right)$, KS diastolinis skersmuo buvo didesnis nei $60 \mathrm{~mm}$. Diastolinè KS funkcija buvo normali, taip pat ir tarpskilvelinès pertvaros bei užpakalinès KS sienelès storių santykis. Taigi tiriant didelio ūgio jaunus krepšininkus (ir kitų šaku sportininkus), $60 \mathrm{~mm}$ KS diastolinis skersmuo neturètų būti laikomas „,nepajudinama“ viršutine normos riba. Kol kas nèra ištirta pakankamai daug jaunų krepšininkų, kad iš ju echokardiografijos rodiklių galima būtų nustatyti KS dydžio (ne tik vidinio skersmens) normos ribą apskritai. Pirmiausia reikètų atsižvelgti į tiriamojo kūno matmenis, nes kai kurių sportininkų jie būna issūdingai dideli.

Nustatème reikšmingai didesni krepšini žaidžiančiu paaugliu $(1,00 \pm 0,13 \mathrm{~m} / \mathrm{s})$ ir jaunų suaugusiuju $(0,88 \pm 0,12 \mathrm{~m} / \mathrm{s})$ ankstyvo maksimalaus kraujotakos pro mitralini vožtuvą greiti (E), palyginti su sveikų suaugusių nesportuojančiuju $(0,75 \pm 0,06 \mathrm{~m} / \mathrm{s})$, esant ramybès būsenai. Tai sutampa su kitu autoriu tyrimu rezultatais, nurodančiais statistiškai reikšmingai didesni plento dviratininku E nei sveiku jaunu nesportuojančiujų 17-mečių (atitinkamai $0,87 \pm 0,17$ ir $0,71 \pm 0,14 \mathrm{~m} / \mathrm{s}$ ) (Hoogsteen et al., 2003), tačiau šie duomenys prieštarauja kitu pateikiamiems: lyginant ivvairių šakų 14-18 metų amžiaus sportininku ir nesportuojančiu bendraamžiu ankstyvos (pasyvios) diastolinès kraujotakos pro mitralini vožtuvą maksimalius greičius, toks skirtumas nenustatytas (Makan et al., 2005). Reikšmingo skirtumo tarp sportininkų ir sveikų nesportuojančiujų diastolinès funkcijos (vertinamos E/A), esant ramybès būsenai, paprastai nenustatoma (neaptikome ir mes), tačiau kartais sportininkų E / A būna reikšmingai didesnis (geresnè diastolinė funkcija), nors dažniausiai tai susiję su gerokai retesniu atletų širdies susitraukinejjimu (Caso et al., 2000).

Nors miokardo dilataciją ir hipertrofiją (KS masę, sienelès storị ar ertmès skersmeni) priimta skaičiuoti atsižvelgiant i kūno dydi ir dalijant absoliučią reikšmę iš tiriamojo kūno paviršiaus ploto, būtų neišvengiama klaidingo duomenų interpretavimo, lyginant labai skirtingų antropometriniu duomenu tiriamuosius. Jei vardiklio ir skaitiklio laipsnio rodikliai nesutampa, širdies dydžio parametrai iškreipiami, o ne reikiamai indeksuojami. Todèl lygindami skirtingo amžiaus ir antropometrinių duomenų tiriamujų echokardiografinius rodiklius naudojomès vengru kardiologu rekomendacijomis ir tarpskilvelinès pertvaros, KS užpakalinès sienelès storị, ertmès skersmeni dalijome iš kūno paviršiaus ploto, pakelto 1 / 2 laipsniu (George et al., 1999; Pavlik et al., 2001). Retsykiais KS masès indeksavimas atliekamas dalijant ją iš žmogaus ūgio (de Simone et al., 1992), tačiau hipertrofijos nustatymo kriterijaus nèra.

17-28 metų krepšininkų ir sveikų nesportuojančiu echokardiografinių rodiklių vidurkio lyginimo rezultatai parode, kad nuo kūno dydžio priklauso širdies morfologiniai rodikliai: pavyzdžiui, pašalinus jo ittaką (absoliučias KS tūrio ir sieneliu storio reikšmes padalijus iš tiriamojo kūno paviršiaus ploto), gautas santykinis KS užpakalinès sienelès storis tarp minètu grupių reikšmingai nebesiskyrè $(\mathrm{p}>0,05)$. KS masę padalijus iš ivvairaus amžiaus tirtujų ūgio, pakelto $e$ laipsniu, skirtumo tarp grupių statistinis reikšmingumas sumažejjo arba išnyko (žr. 2 lent.). Panašius rezultatus gavo ir italai, tyrę tinklininkus: po korekcijos pagal kūno dydị dauguma absoliučiu (neindeksuotu) rodiklių, tapę santykiniais, nebesiskyrè nuo sveiku nesitreniruojančiu asmenu (Zeppilli et al., 1995). Be to, nustatème reikšmingą tiesioginę koreliaciją tarp antropometriniu ivairaus amžiaus krepšininku rodiklių ir KS dydžio parametru. Vis tik nustatytas reikšmingas $(p<0,05)$ skirtumas tarp suaugusių krepšininku ir nesportuojančiu jų bendraamžių santykinio tarpskilvelinès pertvaros storio $(\mathrm{p}<0,001), \mathrm{KS}$ masès indekso $\mathrm{g} / \mathrm{m}^{2}(\mathrm{p}<0,01)$ ar $\mathrm{g} / \mathrm{m}^{\mathrm{e}}(\mathrm{p}<0,05)$, santykinio KS sienelès storio $(p<0,01)$ leidžia teigti, kad miokardas dèl krepšininkų fizinio krūvio metu susidarančios hemodinaminès apkrovos 
adaptuojasi prie jos daugiausia dèl sieneliu hipertrofijos. Vieno iš pirmuju pasaulyje atlikto echokardiografinio tyrimo metu taip pat nustatytas reikšmingai didesnis profesionalių krepšininku KS užpakalinès sienelès storis (ir vidinis KS skersmuo) lyginant su panašaus kūno dydžio kontrolinès grupès sveikų nesportuojančiu bendraamžių rodikliais (Roeske et al., 1976). Beje, profesionalių krepšininkų $(n=10)$ echokardiografinių rodiklių imties vidurkiai yra labai panašūs į mūsų tyrimo metu gautus.

Straipsniuose retai būna pateikti tinkamai indeksuoti santykiniai sportininku miokardo hipertrofijos rodikliai, kad būtų galima juos palyginti su savo gautaisiais. 22 metų kalnų dvikovès meistrų vidutinis santykinis KS užpakalinès sienelès storis buvo panašus, tarpskilvelinès pertvaros storis - mažesnis, o vidinis KS skersmuo didesnis už mūsų tirtų krepšininkų grupių rodiklių vidurkius (George et al., 1999).

Mūsu echokardiografinio tyrimo rezultatai taip pat leidžia trumpai aptarti prieš 20 metų Kanados tyrèjų paskelbtus duomenis. Ištyrus 11 maždaug 20-ties metų amžiaus studentų krepšininkų ir palyginus jų širdies struktūrą su sveikų panašaus ūgio bendraamžiu, statistiškai reikšmingo skirtumo tarp grupių tiriamujų KS užpakalinės sienelès storio, tarpskilvelinès pertvaros storio ir vidinio skersmens absoliučių dydžių nenustatyta, o krepšininkų santykinis (padalytas iš kūno paviršiaus ploto) KS skersmuo buvo netgi mažesnis už sveikų bendraamžių (Wolfe et al., 1985). Panašius rezultatus gavo ir amerikiečiu kardiologai, ištyrę studentes krepšininkes ir palyginę jų miokardo struktūrą su sveikų bendraamžių (Crouse et al., 1992). Tad galima manyti, kad absoliutūs širdies dydžio rodikliai daugiausia priklauso nuo krepšininkų antropometrinių duomenų. Indeksavus miokardo hipertrofijos ar dilatacijos rodiklius pagal kūno dydi, reikšmingo skirtumo tarp krepšininku ir sveikų nesportuojančiujų galima ir neaptikti. Tai neprieštarauja kardiologu pateiktai sporto šaku klasifikacijai, pagal kurią krepšinis nèra laikomas dideli poveiki širdies persimodeliavimui turinčia sportine veikla (Pelliccia et al., 1999; Pavlik et al., 2001). Nors šiuo tyrimu nustatėme, kad krepšininkų santykinis KS sienelių storis yra didesnis už sveikų nesportuojančiu suaugusiujų (tai matyti ir palyginus su literatūroje pateikiamais nesportuojančiujų normos dydžiais), santykinis sportininkų ir nesportuojančių KS vidinis skersmuo nesiskyre $(\mathrm{p}>0,05)$, ir vidutinès reikšmès buvo išties panašios i pateikiamas kitų autorių kontrolinès grupès (sveikų nesportuojančiujų) vidutines reikšmes (George et al., 1999). Be to, krepšininkų, tarp jų ir lietuvių, tyrimai parodè, kad tokio meistriškumo aciklinių šakų sportininkų aerobinis pajègumas yra mažesnis, negu galima buvo tikètis, t. y. nustatytas nedidelis jų maksimalusis deguonies suvartojimas (Hunter et al., 1993; Gocentas, Andziulis, 2004), kuris kylant kitu fiziniu ypatybių lygiui nekinta keleriu metu treniruotes laikotarpiu (Hunter et al., 1993). Rungtyniaudami krepšininkai atlieka labai daug intensyvaus nedidelès trukmès fizinio krūvio, o poilsio metu tarp tokios intensyvios fizinès veiklos paprastai jie būna mažai aktyvūs (McInnes et al., 1995; Balčiūnas, Stonkus, 2003). Tai turètų lemti ir treniruotès pobūdi, o visa, kas anksčiau minèta, yra susiję su ne itin ryškia struktūrine širdies adaptacija, nes žinoma, kad ji sveikiems žmonèms yra svarbiausia aerobini pajejgumą lemianti grandis (Bassett, Howley, 2000). Beje, ir Lietuvoje, ir Amerikoje tirti įvairių pozicijų žaidejai buvo laikomi viena krepšininku grupe. Tačiau įdomu paminèti, kad kanadiečiai, nors tyrè vos po $5-6$ sportininkus, palyginę ižaidejjų ir krašto bei vidurio puolejų echokardiografinius rodiklius, nustate koncentriškesni ižaideju KS persimodeliavimą. Taigi krepšininkų struktūrinè širdies adaptacija gali priklausyti nuo jų žaidimo pozicijos. Tai gali būti susiję ir su skirtingų pozicijų krepšininkų antropometriniais rodikliais, taip pat su ju fiziniu pajègumu, pratybu ir rungtynių metu atliekamo fizinio krūvio pobūdžiu bei intensyvumu (Rodriguez-Alonso et al., 2003), tačiau KS sienelès storejjimas dèl reguliaraus fizinio krūvio pirmiausia siejamas su arterinio kraujospūdžio dydžiu ilgo fizinio krūvio metu (Karjalainen et al., 1997). Koncentriškesni kairiji skilveli nei galima būtų tikètis tarp ištvermès šaku sportininkų yra nustatę ir kiti autoriai, tyrę didžiausio meistriškumo bėgikus (Palazzuoli et al., 2002) ir vandensvydininkus (Pavlik et al., 2005).

Ištirtų ivvairaus amžiaus krepšininkų vidutinis santykinis KS sienelès storis $(0,402)$ buvo gerokai didesnis už vidutini jaunu suaugusių kalnų dvikovès sportininku $(0,373)$ (George et al., 1999), tačiau beveik toks pats, kaip vidutinis 171 ištirtų 15-19 metu futbolininku $(0,397)$ (Somauroo et al., 2001). Tai rodo, kad atliekant fizini krūvị per sportinių žaidimų su kamuoliu treniruotę susidaro panaši miokardo apkrova, kuri lemia atitinkamą KS struktūrinę adaptaciją. 


\section{IŠVADOS}

1. Daugumai jaunų krepšininkų nebūdinga ryški miokardo hipertrofija: santykiniai kairiojo širdies skilvelio dydžio rodikliai neviršija arba labai saikiai viršija normos ribas ir priklauso nuo treniravimosi stažo. Absoliutūs miokardo morfologiniai parametrai daugiausia priklauso nuo krepšininkų antropometrinių rodiklių - i tai reikia atsižvelgti tiriant įvairiu pozicijų žaidejus.
2. 9-12 metu krepšininkų santykinis kairiojo širdies skilvelio storis yra mažesnis nei $13-16$ metų žaidejju $(\mathrm{p}<0,01)$, o pastaruju nesiskiria nuo 17-28 metų krepšininkų ( $p>0,05)$. Miokardo hipertrofija dèl sieneliu storèjimo krepšininko karjeros metu vystosi gana tolygiai, struktūrinè kairiojo skilvelio adaptacija prie krepšinio treniruotès neigiamai nepaveikia diastolinès jo funkcijos.

\section{LITERATŪRA}

Allen, H. D., Goldberg, S. J., Sahn, D. J. et al. (1977). A quantitative echocardiographic study of champion childhood swimmers. Circulation, 55, 142-144.

Balčiūnas, M., Stonkus, S. (2003). Analysis of predominant intensity of physical load in basketball players of different ages during competition and training. Human movement, 2, 17-21.

Bassett, D., Howley, E. T. (2000). Limiting factors for maximum oxygen uptake and determinants of endurance performance. Medicine and Science in Sports and Exercise, 32 (1), 70-84.

Caso, P., D'Andrea, A., Galderisi, M. et al. (2000). Pulsed Doppler tissue imaging in endurance athletes: relation between left ventricular preload and myocardial regional diastolic function. American Journal of Cardiology, 85 (9), $1131-1136$

Crouse, S. F., Rohack, J. J., Jacobsen, D. J. (1992). Cardiac structure and function in women basketball athletes: Seasonal variation and comparison with nonathletic controls. Research Quarterly for Exercise and Sport, 63 (4), 393-401.

Devereux, R. B., Alonso, D. R., Lutas, E. M. et al. (1986). Echocardiographic assessment of left ventricular hypertrophy: Comparison to necropsy findings. American Journal of Cardiology, 57, 450-458.

Douglas, P. S., O’Toole, M. L., Hiller, W. D., Reichek, N. (1986). Left ventricular structure and function by echocardiography in ultraendurance athletes. American Journal of Cardiology, 58, 805-809.

Du Bois, D., Du Bois, E. F. (1916). A formula to estimate approximate surface area if height and weight be known. Archives of Internal Medicine, 17, 129-171.

George, K., Gates, P., Whyte, G. P., Fenoglio, R. A., Lea, R. (1999). Echocardiographic examination of cardiac structure and function in elite cross trained male and female Alpine skiers. British Journal of Sports Medicine, 33, 93-99.

Gocentas, A., Andziulis, A. (2004). Changes in oxygen consumption of basketball players during recovery after maximal load. Medicina, 40 (6), 569-573.

Gutgesell, H. P., Rembold, C. M. (1990). Growth of the human heart relative to body surface area. American Journal of Cardiology, 65, 662-668.

Hoogsteen, J., Hoogeveen, A., Schaffers, H., Wijn, P. F., van der Wall, E. E. (2003). Left atrial and ventricular dimensions in highly trained cyclists. International
Journal of Cardiovascular Imaging, 19 (3), 211-217.

Hunter, G. R., Hilyer, J., Forster, M. A. (1993). Changes in fitness during 4 years of intercollegiate basketball. Journal of Strength Conditioning Research, 7 (1), 26-29. Karjalainen, J., Mantysaari, M., Viitasalo, M., Kujala, U. (1997). Left ventricular mass, geometry, and filling in endurance athletes: Association with exercise blood pressure. Journal of Applied Physiology, 82 (2), 531537.

Makan, J., Sharma, S., Firoozi, S. et al. (2005). Physiological upper limits of ventricular cavity size in highly trained adolescent athletes. Heart, 91, 495-499.

Manolas, V. M., Pavlik, G., Banhegyi, A. et al. (2001). Echocardiographic changes in the development of athlete's heart in 9 to 20-year-old subjects. Acta Physiologica Hungarica, 88 (3-4), 259-270.

McInnes, S. E., Carlson, J. S., Jones, C. J., McKenna, M. J. (1995). The physiological load imposed on basketball players during competition. Journal of Sports Science, 13 (5), 387-397.

Palazzuoli, A., Puccetti, L., Pastorelli, M. et al. (2002). Transmitral and pulmonary venous flow study in elite male runners and young adults. International Journal of Cardiology, 84, 47-51.

Pavlik, G., Kemeny, D., Kneffel, Z. et al. (2005). Echocardiographic data in Hungarian top-level water-polo players. Medicine and Science in Sports and Exercise, 37 (2), 323-328.

Pavlik, G., Olexo, Z., Osvath, P., Sido, Z., Frenkl, R. (2001). Echocardiographic characteristics of male athletes of different age. British Journal of Sports Medicine, 35, 95-99.

Pelliccia, A., Culasso, F., Di Paolo, F. M., Maron, B. J. (1999). Physiological left ventricular cavity dilatation in elite athletes. Annals of International Medicine, 130 (1), $23-31$

Rodriguez-Alonso, M., Fernandez-Garcia, B., PerezLandaluce, J., Terrados, N. (2003). Blood lactate and heart rate during national and international women's basketball. Journal of Sports Medicine and Physical Fitness, 43 (4), $432-436$.

Roeske, W. R., O’Rourke, R. A., Klein, A., Leopold, G., Karliner, J. S. (1976). Noninvasive evaluation of ventricular hypertrophy in professional athletes. Circulation, 53 (2), 286-291.

Rowland, T. W., Delaney, B. C., Siconolfi, S. F. (1987). 
“Athlete's heart" in prepubertal children. Pediatrics, 79 (5), 800-804.

Sahn, D. J., DeMaria, A., Kisslo, J., Weyman, A. (1978). Recommendations regarding quantitation in $\mathrm{M}$-mode echocardiography: Results of a survey of echocardiographic measurements. Circulation, 58 (6), $1072-1083$.

Sharma, S. (2003). Athlete's heart - effect of age, sex, ethnicity and sporting discipline. Experimental Physiology, 88 (5), 665-669.

Sharma, S., Maron, B. J., Whyte, G. et al. (2002). Physiologic limits of left ventricular hypertrophy in elite junior athletes: Relevance to differential diagnosis of athlete's heart and hypertrophic cardiomyopathy. Journal of American College of Cardiology, 40 (8), 1431-1436.

de Simone, G., Daniels, S. R., Devereux, R. B. et al. (1992). Left ventricular mass and body size in normotensive children and adults: Assessment of allometric relations and impact of overweight. Journal of American College of Cardiology, 20 (5), 1251-1260.

Somauroo, J. D., Pyatt, J. R., Jackson, M., Perry, R. A., Ramsdale, D. R. (2001). An echocardiographic assessment of cardiac morphology and common ECG findings in teenage professional soccer players: Reference ranges for use in screening. Heart, 85, 649-654.

Triposkiadis, F., Ghiokas, S., Skoularigis, I. et al. (2002). Cardiac adaptation to intense training in prepubertal swimmers. European Journal of Clinical Investigation, $32(1), 16-23$.

Wolfe, L. A., Martin, R. P., Seip, R. L. (1985). Absence of left ventricular hypertrophy in elite college basketball players. Canadian Journal of Applied Sports Sciences, $10(3), 116-121$.

Zeppilli, P., Vannicelli, R., Santini, C. et al. (1995). Echocardiographic size of conductance vessels in athletes and sedentary people. International Journal Sports Medicine, 16 (1), 38-44.

\title{
STRUCTURE AND FUNCTION OF LEFT HEART VENTRICLE OF YOUNG BASKETBALL PLAYERS
}

\author{
Tomas Venckūnas ${ }^{1}$, Donatas Vasiliauskas ${ }^{2}$, Jolanta Marcinkevičiene் ${ }^{2}$, Rasa Raugalien $\dot{e}^{2}$ \\ Lithuanian Academy of Physical Education ${ }^{1}$, Institute of Cardiology, Kaunas University of Medicine ${ }^{2}$,
} Kaunas, Lithuania

\begin{abstract}
As basketball players' heart structure and function are poorly investigated at the moment, our study was aimed at revealing peculiarities of long-term cardiac adaptation in players of the most popular sport in Lithuania.

Male basketball players aged between 9 and 28 years $(n=29)$ and healthy (aged between 18 and 25 years) non-athletes (control group, $\mathrm{n}=7$ ) were examined by standard two-dimensionally guided $\mathrm{M}$-mode and Doppler echocardiography. Left ventricular (LV) end-diastolic internal diameter, posterior wall thickness as well as interventricular wall thickness were measured. LV structure and size were also evaluated calculating relative wall thickness (dividing the sum of posterior wall and interventricular wall thicknesses by internal diameter) and its mass (standard equation), respectively. Diastolic LV function was assessed measuring the peak early (E) and peak late (A) transmitral flow velocity and calculating their ratio (E / A).

Basketball players' cardiac dimensions were related significantly to their body size. Significant differences in absolute internal LV diameter between age groups dissapeared after allometric scaling for differences of body surface area. Commensurate relative LV internal diameter was observed in players versus healthy adult controls ( $p>0.05$ ). However, adult athletes had greater both absolute as well as allometrically scaled LV mass than that of peer non-athletes. In addition, basketball players, in spite of their young age, possess significantly more concentric (with greater relative wall thickness) LV myocardium as compared with healthy non-athletes. No signs of diastolic LV dysfunction was evident in players, with E / A being nonsignificantly higher than that of sedentary controls $(p>0.05)$.

Basketball training-induced LV hypetrophy in young players seems to be modest at best. Tendency towards physiological thickenning of myocardial walls during increasing age and training experience was observed.
\end{abstract}

Keywords: allometric scaling, basketball, echocardiography, left ventricular hypertrophy.

Gauta $2005 \mathrm{~m}$. balandžio $20 \mathrm{~d}$.

Received on April 20, 2005

Priimta 2005 m. gegužès $18 \mathrm{~d}$.

Accepted on May 18, 2005
Tomas Venckūnas

Lietuvos kūno kultūros akademija

(Lithuanian Academy of Physical Education)

Sporto g. 6, LT-44221 Kaunas

Lietuva (Lithuania)

Tel +370 37302671

E-mailt.venckunas@lkka.lt 